Plant Tissue Cult. \& Biotech. 20(1): 91-99, 2010 (June)

$\overline{\text { PTC\&B }}$

\title{
Molecular Characterization of 12 Mango Germplasm Using RAPD markers
}

\author{
R. C. Jena* , K. C. Samal, P. K. Chand ${ }^{1}$ and B. K. Das \\ Biotechnology cum Commercial Tissue Culture Centre, Orissa University of Agriculture \\ and Technology, Bhubaneswar-751003, Orissa, India
}

Key words: Molecular characterization, Mango germplasm, Dversity

\begin{abstract}
Randomly amplified polymorphic DNA (RAPD) markers were used for the genetic variation and relationship analysis among 12 Mango (Mangifera indica L.) germplasm. Five oligonucleotide primers were employed to amplify DNA from 12 cultivars. PCR amplification with five primers generated 45 reproducible, clear and distinct bands, out of which 41 bands are considered polymorphic and the remaining four fragments $(8.88 \%)$ monomorphic. The size of amplified product ranged from 200 (RPI-5) to 3000 base pairs (RPI-1) with an average of nine bands per primer. The average polymorphism in all the 12 cultivars using the five primers was found to be $91.91 \%$. Among all the primers RPI-2 and RPI-4 have shown $100 \%$ polymorphism while RPI-5 was found to be least polymorphism (81.81\%). One specific band, namely was found with RPI-5, in a particular variety, Chiratpuri. The UPGMA (Unweighted Pair Group Method of Arithmetic Mean) dendrogram based on Jaccard's similarity coefficient segregated the 12 mango germplasm into two clusters. Langra, Chiratpuri, Pravasankar, Alphanso, Sindhu and Kesar formed one cluster and rest six mango germplasm grouped together into another cluster. Sindhu and Alphanso cultivar pair was very close to each other with highest similarity coefficient (0.78), which was comparatively higher than all other cultivar pairs. On the other hand, Pravasankar and Neelam cultivar pair was more distinct to each other with the lowest intervarietal similarity coefficient 0.38 . This study showed clearly that cultivars from Orissa unveiled maximum diversity and indicated the potential of RAPD markers for the identification of management of mango germplasm for breeding purposes.
\end{abstract}

\section{Introduction}

Mango (Mangifera indica L) is an important member of Anacardiaceae believed to have originated in the Indo-Burma region (Popenoe 1927, Mukherjee 1951, Decandolle 1904). Mango, the choicest fruit of India is rightly titled as the 'King of fruits' because of its wide adaptability, high nutritive value, richness in

*Author for correspondence. <jena_ramchandra@yahoo.co.in>. 1Postgraduate Department of Botany, Utkal University, Bhubaneswar-751004, Orissa. India. 
variety, delicious taste, excellent flavor, attractive appearance and popularity among masses. Mango is the National fruit of India and the subcontinent has the richest wealth of Mango germplasm. It is also the most important fruit of Orissa grown from time immemorial. More than 1000 varieties of mango are available in Orissa (Parida and Rao 1988). In Orissa the total existing are under mango is 140060 ha, while the fruit bearing area is about 108480 ha. The total mango production is about 431.41 thousand tons with productivity of 4 ton/ha (www.indiastat.com, 2007).

There is a considerable confusion regarding cultivar identification, because as presently several mango cultivars of many synonyms in different regions which make identification difficult. Similar cultivars grown in different areas are known by different names. For example, Banganpalli is known by different names like Baneshan, Chepta, Chaptai, Safeda etc. However, the performance of varieties is found to vary under different climatic conditions (Singh 1978) and also different cultivars sometimes appear under the same name. So identification differentiation of cultivars through morphological features alone is inefficient and inaccurate. This is further compounded by the perennial nature of the crop. The morphological markers are influenced by the environmental conditions, making identification labour intensive and time consuming. Biochemical markers such as isoenzyme and protein patterns though minimally influenced by the environment offer limited polymorphism and often do not allow distinction between closely related genotypes. Many of these drawbacks of morphological and biochemical markers can be overcome through direct identification of genotypes with DNA based genetic markers. Recently reliable DNA based genetic markers have been developed and introduced for mango cultivar identification. A simple, reliable, unambiguous, fast and cost effective determination of genetic diversity in plant varieties is essential for proper varietal identification, classification, and conservation, finally helpful for plant improvement. Not only the DNA-based genetic markers are useful for varietal identification but also further estimation of genetic diversity and relatedness between mango accessions, hybrids are expected to play an important role in the future plant improvement programs.

The molecular marker i.e. RAPD, ISSR, and Microsatellite are widely used for varietal identification and genetic diversity analysis. The RAPD method has advantages over other kinds of DNA-based genetic markers; it is relatively quick, easy to perform, cheaper, highly informative, need not only prior information of template DNA sequence and synthesis of specific markers. 


\section{Materials and Method}

Twelve mango cultivars (Mangifera indica L.) namely Banganpalli, Suvernarekha, Vanraj, Totapuri, Neelum, Mulgoa, Kesar, Sindhu, Alphanso, Pravasanker, Chiratpuri and Langra were obtained from the orchard of OUAT, Bhubaneswar, Orissa. In order to carry out RAPD analysis, young leaves from each of the twelve mango germplasm were collected from orchard and washed thoroughly using double distilled water. DNA was extracted following CTAB method. One gram of leaf tissue was ground to fine powder using pre chilled mortar and pestle with liquid nitrogen. Ten $\mathrm{ml}$ of extraction buffer ( $2 \% \mathrm{CTAB}(\mathrm{w} / \mathrm{v}), \mathrm{NaCl} 1.5$ M, Tris $\mathrm{HCl}$ pH 8.0 (100 mM), EDTA pH 8.0 (20 mM), 2 \% v/v PVP, $2 \%$ (V/v) $\beta$ mercaptoethanol) was preheated to $60^{\circ} \mathrm{C}$ and added to the centrifuge tubes containing ground leaves. The tubes were shaken gently to form slurry and then incubated at $60^{\circ} \mathrm{C}$ for one hr with intermittent shaking for every ten min. After incubation, the tubes were cooled to room temperature. Ten $\mathrm{ml}$ of chloroform : isoamyl alcohol (24:1) mixture were added and mixed properly by inverting the tubes 20 - 25 times to form an emulsion and centrifuged at $12000 \mathrm{rpm}$ for $20 \mathrm{~min}$ at room temperature. The supernatant was carefully transferred to fresh tubes and the second extraction with the above mixture (chloroform : isoamyl alcohol (24:1) was performed because of the cloudy nature of aqueous phase due to presence of PVP. Again the clear aqueous phase was transferred to a new tube and was precipitated with two volumes of pre chilled $\left(-20^{\circ} \mathrm{C}\right) 95 \%$ ethanol and sodium acetate (final conc. $0.3 \mathrm{M}$ ), and gently mixed by inverting up and down (ten times) to produce fibrous DNA and incubated at $-20^{\circ} \mathrm{C}$ for a minimum of one hr. The samples were centrifuged at 10,000 rpm for $15 \mathrm{~min}$. The supernatant was discarded and the pellet was washed two - three times twice and thrice with $70 \%$ ethanol. Decanted the supernatant and air dried DNA pellet at RT until the whitish pellet turned to transparent and re suspended in $300 \mu \mathrm{l}$ of TE Buffer and $6 \mu \mathrm{l}$ of RNAase $(10 \mu \mathrm{g} / \mu \mathrm{l})$ was added incubated at $37^{\circ} \mathrm{C}$ for two $\mathrm{h}$ (RNAase treatment helped achieving in proper genomic DNA). To this $600 \mu \mathrm{l}$ of ice chilled ethanol and $10 \mathrm{ml}$ of $3 \mathrm{M}$ sodium acetate was added and incubated at $-20^{\circ} \mathrm{C}$ for one hr to re-precipitate DNA. The solution was centrifuged at 10,000 rpm for 15 minutes; DNA pellet was dried at $37^{\circ} \mathrm{C}$ and re suspended in $300 \mu \mathrm{l}$ of Tris-EDTA (TE) buffer. All the centrifugation steps were carried out at RT. The yield of DNA was measured using a UV Spectrophotometer at $260 \mathrm{~nm}$. The purity of DNA was determined by estimating the ratio of absorbance at $260 \mathrm{~nm}$ to that of $280 \mathrm{~nm}$. DNA concentration and purity was also determined by running the samples on $0.8 \%$ agarose gel electrophoreses. The concentration of DNA was calculated by the intensities of band when compared with lambda DNA marker. The nucleic acid concentration was also estimated following (Sambrok et al. 1989). 
The basic procedure reported by Williams et al. (1990) for PCR was followed by slight modifications. DNA amplification was done using five arbitrary decamer primers (Bangalore Genei, Bangalore, India). PCR reactions were performed on each DNA sample in a $25 \mu$ reaction mixture containing 1x PCR Buffer (10 mM Tris $\mathrm{HCl}$ pH 8.3; $50 \mathrm{mM} \mathrm{KCl}), 2 \mathrm{mM} \mathrm{MgCl}_{2}, 200 \mu \mathrm{M}$ dNTP each, $1 \mathrm{U}$ of Taq DNA polymerase (Genei, Bangalore) $0.5 \mu \mathrm{M}$ of single primer (Genei, Bangalore), $50 \mathrm{ng}$ of template DNA and rest amount of sterile nuclease and protease free water. Reactions without DNA were used as negative control. DNA amplification were carried out in a DNA thermocycler (BIO RAD, USA). The thermocycler was programmed for an initial step of $3 \mathrm{~min}$ at $94^{\circ} \mathrm{C}$ followed by 44 cycles of one minute annealing at $37^{\circ} \mathrm{C}$ and extension at $72^{\circ} \mathrm{C}$ for two min. After the last cycle, a final extension at $72^{\circ} \mathrm{C}$ for seven min was added to allow complete extension of all amplified fragments. After completion of cycling program, reactions were held at $4^{\circ} \mathrm{C}$ at the end. Amplified DNA fragments were separated on $1.5 \%$ agarose gel stained with ethidium bromide $(1.0 \mu \mathrm{g} / \mathrm{ml})$. Running buffer containing Tris-base, boric acid and EDTA (TBE), pH 8.0 was used for electrophoresis and for preparing gels. Wells were loaded with $12 \mu \mathrm{l}$ of amplified sample and $2 \mu \mathrm{l}$ of $6 \mathrm{x}$ loading dye. Electrophoresis was conducted at $70 \mathrm{~V}$ for four hr and the gel with amplified fragments were visualized and photographed under UV light. Medium range DNA ruler was used as a molecular marker (Bangalore genei, India) to know the size of the fragments.

Since nearly all RAPD markers are dominant, it is assumed that each band represented the phenotype at a single allelic locus (Williams et al. 1990). All distinct bands that were clearly resolved on the gels were thereby given identification numbers according to their position and scored visually as 1 and 0 on the basis of their presence and absence, separately for each individual and each primer. Bands that could not be confidently scored were regarded as missing data. The scores obtained in the RAPD analysis using all the primers were then pooled to create a single data matrix and used to estimate gene diversity, genetic similarity, polymorphic loci and to construct a UPGMA dendrogram among populations using a computer program NTSYS-PC (version 2.02) (Rohlf 1993). The program also generated a dendrogram (Fig. 1), which grouped the varieties on the basis of Jaccard's Similarity coefficient using Unweighted Pair Group Method with Arithmetic Average (UPGMA) cluster analysis (Sneath and Sokal 1973). The Jaccard's similarity co-efficient between each pair of genotypes were used to construct a dendrogram. Genetic similarity values defined as the fraction of shared bands between the RAPD profiles of any two individuals on the same gel were calculated from RAPD markers of the same molecular weight on the data matrix according to the formula given below:

Similarity index $(\mathrm{SI})=2 \mathrm{Nxy} / \mathrm{Nx}+\mathrm{Ny}$ 
where, Nxy is the number of RAPD bands shared by individual $\mathrm{x}$ and $\mathrm{y}$, respectively.

$\mathrm{Nx}$ is the number of bands in individual $\mathrm{x}$,

$\mathrm{Ny}$ is the number of bands in individual $\mathrm{y}$.

\section{Results and Discussion}

Mango with chromosome number $2 \mathrm{n}=40$ has a DNA content around 439 million bases (Armuganathan and Earle 1991). In this study, DNA from 12 mango cultivars was amplified using five primers. These five primers generated 45 RAPD bands with size ranging from 200 - $2000 \mathrm{bp}$. Out of the 45 bands, 42 (93.33\%) were found to be polymorphic, in a previous study Lopezvalenzuela et al (1997) reported that 74\% RAPD bands as polymorphic among 15 mango cultivars. Ravishankar et al. (2000) reported that 73\% RAPD bands as polymorphism (130 polymorphic bands out of 178 bands) in the 18 Indian mango cultivars. The five different primers generated various banding patterns, ranging from 8 - 11. The primer RPI-5 produced the highest number of band (11) out of which 9 bands are polymorphic, thus it represented a higher level of polymorphism. On the other hand, the primer RPI-1, RPI-2, RPI-3 and RPI-4 generated 8, 8, 8, 8 polymorphic bands, respectively. These results gave an average of 8 polymorphic bands per primer are shown in Table 1. The banding patterns of 12 mango germplasm using RPI-5 primers are shown in Fig. 1. Kumar et al. (2001) reported Jaccard's similarity in the range of 61 to $95 \%$. Rahman et al. (2007) reported Jaccards similarity in the range of 14.29 to $87.30 \%$. Obviously, the present varieties were genetically more diverse than that used by the above markers (Table 2). Pair wise comparison of DNA profiles of the 12 mango germplasm showed inter-cultivar similarity index for Sindhu vs. Alphanso (0.78), which were comparatively higher than all other cultivar pairs.

On the other hand, inter-cultivar similarity index for Pravasankar vs. Mulgoa (0.38) cultivar pair was comparatively lower than all the other cultivar pairs. One specific band was identified with RPI-5 in a particular variety, Chiratpuri of $900 \mathrm{bp}$. The position of a specific band clearly indicating a particular variety identification, viz. Chiratpuri. A dendogram constructed on the basis of Jaccard's similarity coefficient separated all the 12 mango cultivars into two main clusters at 0.50 similarity coefficient, Fig. 2. Langra, Chiratpuri, Pravasanker, Alphanso, Sindhu and Kesar formed cluster II and the remaining six mango germplasm were grouped in cluster I. In cluster II Langra alone formed sub cluster IIB and remaining five were grouped in sub cluster IIA. In sub cluster IIA, chiratpuri, a off-season cultivar, alone formed a separate distinct sub-sub cluster IIA1 the remaining five mango germplasm were grouped in sub-sub cluster-IIA2. 


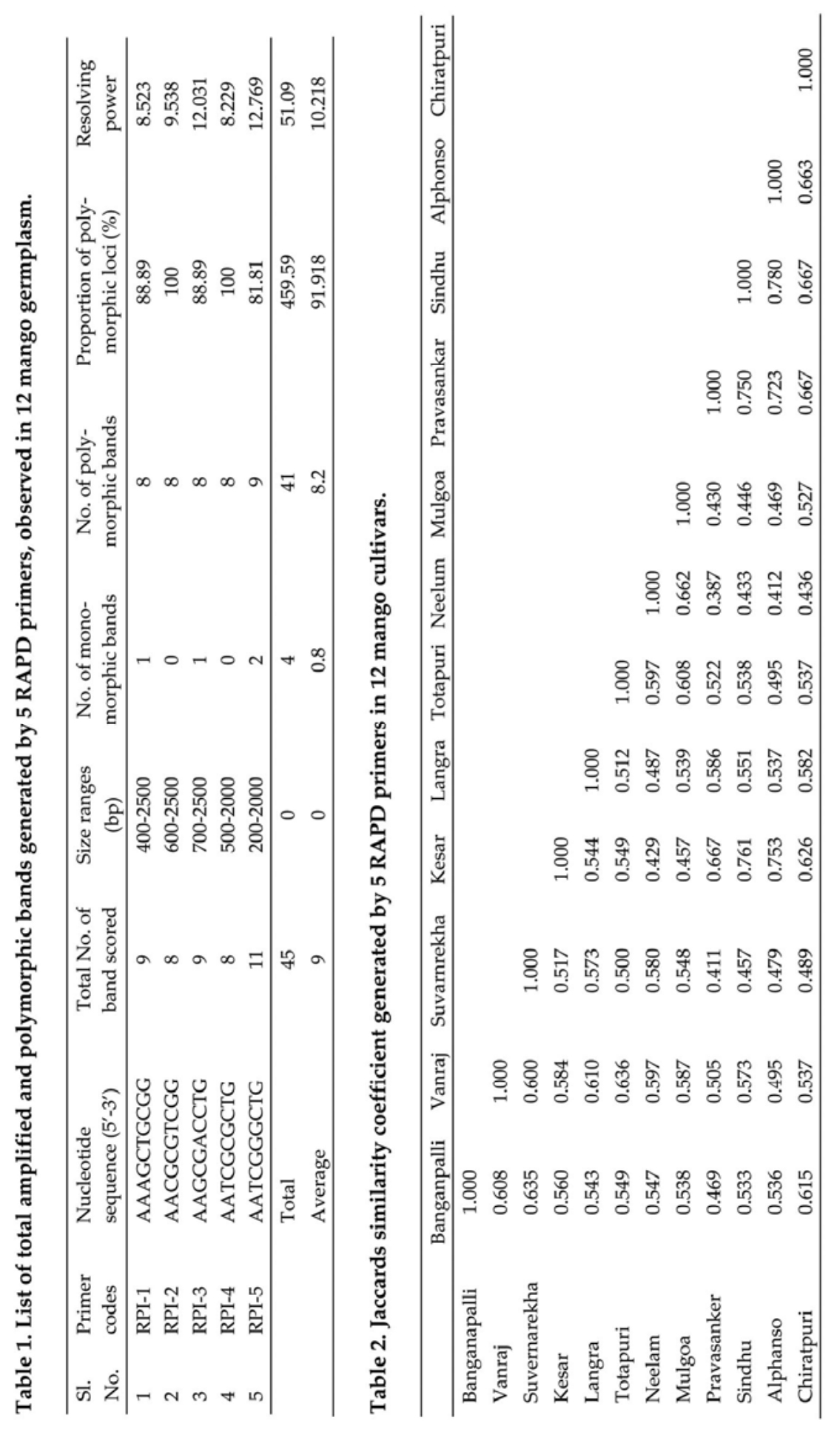


Pravasankar alone formed one group on the other hand sindhu vs alphanso grouped at the lower level of genetic distance i.e 0.78. In cluster I Banganapalli vs. Suvernarekha formed sub cluster IA and the remaining four grouped in sub cluster-IB. In sub cluster IB Vanraj, Totapuri; Neelum, Malgua grouped separately with lower level of genetic distance 0.63 and 0.66 , respectively. In here conforms the same results using the NJ method.

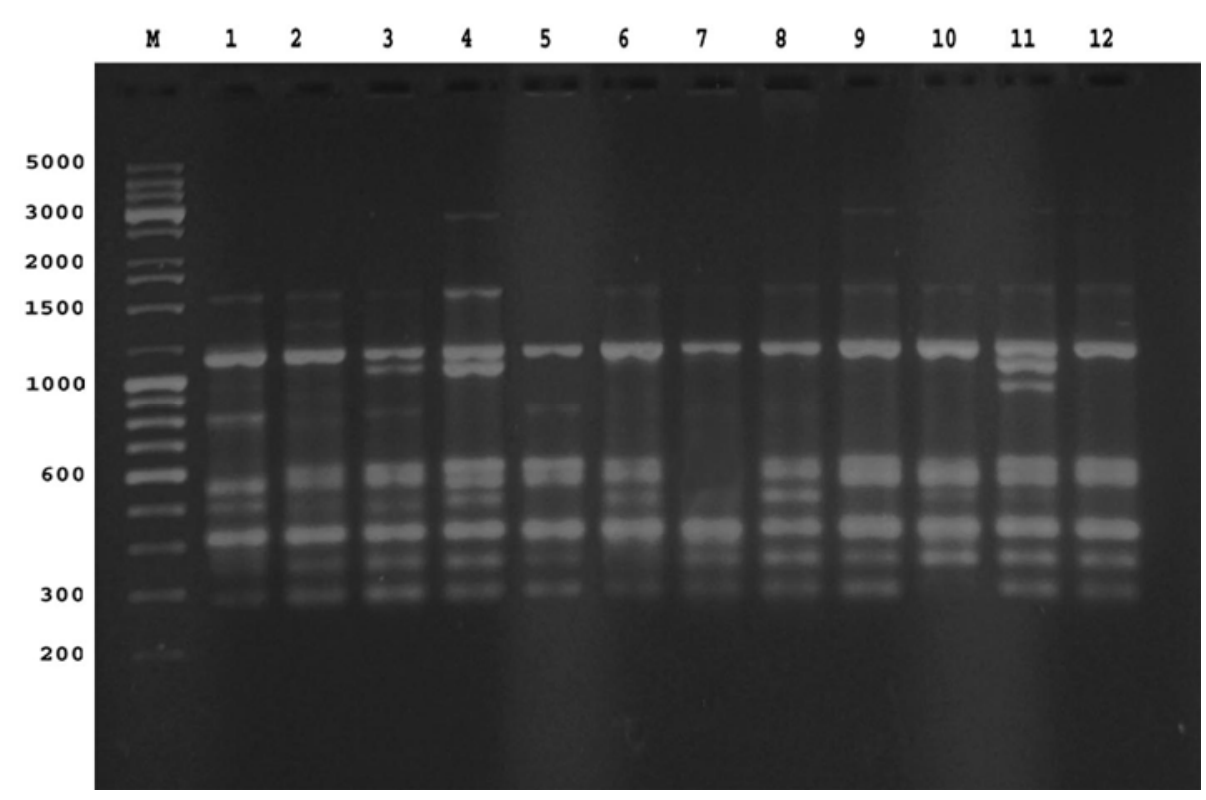

Fig. 1. RAPD-PCR amplification product of 12 different mango germplasm viz. 1. Banganpalli, 2. Suvernarekha, 3. Vanraj, 4. Totapuri, 5. Neelum, 6. Mulgoa, 7. Kesar, 8. Sindhu, 9. Alphanso, 10. Pravasanker, 11. Chiratpuri, 12. Langra by using Genei, Bangalore primer RPI- C Series, RPI-5 (5'-AATCGGGCTG-3') indicated in Fig. 1. The amplification product was fractioned in a $1.5 \%$ agaroge gel. Lane M: Low Range DNA Ruler plus.

This study of RAPD analysis revealed a high degree of genetic diversity among the cultivars. The origin and geographical distribution of these cultivars might be the cause of the high degree of genetic diversity found during RAPD analysis. Banganpalli, Totapuri, Neelum and Mulgoa are South Indian varieties, whereas Langra is a North Indian variety. Kesar, Sindhu and Alphonso are cultivated widely in Western India and prpbably originated there. Other cultivars, Pravasankar, Suvernarekha and Chiratpuri are largly distributed in Eastern India. The results of this research study clearly indicate that RAPD markers can be successfully employed to assess genetic relatedness among the cultivars. RAPD is less expensive than other molecular techniques like RFLPs (Restriction Fragment Length Polymorphism), as no hybridization and no use of 
radioisotopes is required; therefore it is more convenient for use in research centers in developing countries.

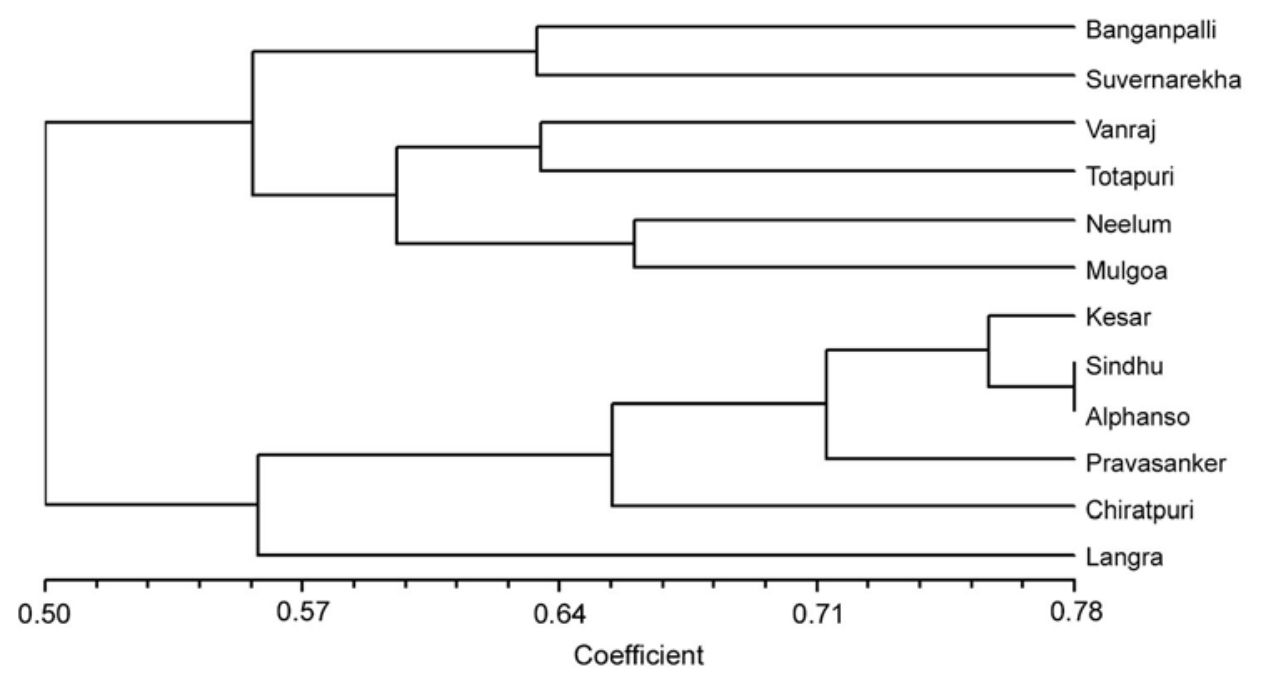

Fig. 2. UPGMA dendrogram based on Jaccard's Similarity coefficient revealing genetic relationships among 12 mango germplasm using RAPD profile data.

As mango improvement programs are very recent to the Indian subcontinent, this information generated here will be of great use for selection of diverse parents for mango hybridization and other related crop improvement programs.

\section{Acknowledgements}

Authors are grateful to the Ministry of Agriculture, Government of India for financial support.

\section{References}

Armuganathan K and Earle ED (1991) Nuclear DNA content of some important plant species. Plant Molecular Biology Reporter 9: 208-18.

De Candolle A (1904) Origin of cultivated plants. Kegan Paul, Trench, London.

Kumar NVH, Narayanaswamy P, Prasad DT, Mukunda GK and Sondur SN (2001) Estimation of genetic diversity of commercial mango (Mangifera indica L.) cultivars using RAPD markers. J. Hort. Sci. Biotech. 76(5): 529-533.

Lopez-Valenzuela JA, Martinez O and Pardes OL (1997) Geographic differentiation and embryo type identification in Mangifera Indica L. cultivars using RAPD markers. Hort. Sci. 32: 1105-1108.

Mukherjee SK (1951) The Origin of mango. Ind. J. Genetics 2: 49. 
Molecular Characterization of Mango Germplasm

Popenoe W (1927) Manual of tropical and subtropical fruits. Mcmillan, New York, USA.

Rahman ML, Rabbani MG, Siddique MNA, Rahaman MA, Garvey EJ and Rahaman EHMS (2007) Molecular Characterization of 28 Mango Germplasm Using RAPD. Plant Tissue Culture \& Biotech. 17(1): 71-77.

Rao DP and Parida GN (1988) Horticulture in Orissa, Mango special No.14.

Ravisankar KV, Lalitha A, Dinesh MR and Anand L (2000) Assesment of genetic reletedness among mango cultivars of India using RAPD markers. J. Hort. Sci. Biotech. 75(2): 198-201.

Rohlf FJ (1993) NTSYS-pc. Numerical taxonomy and multivariate analysis: verson 2.02. Applied Biostastistics, New York.

Sambrook J, Fritsch EF and Maniatis T (1989) Molecular cloning : A laboratory manual. Cold Spring Harbor Laboratory Press, Cold Spring, Harbour, New York, USA.

Singh RN (1978) Mango. Indian Council of Agricultural Research, New Delhi. pp. 39-55

Sneath PHA and Sokal RR (1973) Numerical taxonomy. Theor. Appl. Genet. 93: 613-617.

Williams JGK, Kubelic AR, Livak KJ, Rafalski JA and Tingey SV (1990) DNA polymorphisms amplified by arbitrary primers are useful as genetic markers. Nucli Acids Res. 18(22): 6531-6535.

www.indiastat.com, (2007). Production and productivity of mango in Orissa. 